\title{
International liability and compensation regimes as a tool of strengthening the balance between shipping economy and marine environment protection
}

\author{
Justyna Nawrot $^{1,{ }^{*}}$, and Zuzanna Pepłowska Dąbrowska ${ }^{2}$ \\ ${ }^{1}$ University of Gdańsk, Faculty of Law and Administration, 6 Jana Bażyńskiego St., 80-309 Gdańsk, \\ Poland \\ ${ }^{2}$ Nicolas Copernicus University, Law and Administration Faculty, 3 Władysława Bojarskiego St., \\ 87-100 Toruń, Poland.
}

\begin{abstract}
The basic requirements concerning the marine environmental protection introduced under auspices of the IMO refers to ship's construction and ship's operation and are recognized as a technical in nature or connected with seafarers qualifications. The aim of the article is to emphasis the importance of private law instruments, especially financial security instruments as a tool of strengthening the maritime safety and marine environmental protection in the recent IMO' works. Attempts to create global system of liability and compensation, especially by introducing the financial security instruments, stays in line with the IMO's public policy and aims to increase the effectiveness of the international safety standards at sea. Firstly that new instrument has been introduced as a response to environmental threats inherent in carriage of oil as cargo. Soon it became a standard provision of many others environmental threats, such as hazardous and noxious substances, bunker oil or wreck removal and lately introduced to Maritime Labour Convention prepared under ILO's auspices. By analyzing provisions of selected maritime conventions, Authors aim to demonstrate that the financial security instruments are seen not only as a commercial tools supporting the claimants chance to obtain full/adequate compensation but also as an element of strengthening public goals.
\end{abstract}

\section{Introduction}

International Maritime Organisations (hereinafter: IMO) describes its goals as "cleaner and safer oceans". Despite that shipping had remained largely private industry, states were supporting IMO in development of internationally harmonised standards enhancing safety and environmental protection through introduction new technical and operational standards, as well as a new control mechanism strengthening the coastal and port states rights. But

\footnotetext{
${ }^{*}$ Corresponding author: j.nawrot@prawo.univ.gda.pl
} 
IMO's ambition reached further - not only to prevent the accidents and pollution but also to provide compensation for damages. Thus, aside of public in nature, substantial norms aiming at minimizing the risk of pollution or accident, new important element of international maritime law was introduces to increase the effectiveness of the international maritime safety standards. New financial security instruments were introduced firstly as a response to environmental threats, but lately they were adopted also to provide effective protection of social goals. This paper aims to demonstrate that private in nature, financial instruments stay in line and support public goals of IMO's policy. The basic research method used by Authors was hermeneutic analysis, which allows to reconstruct the foundation axiology for introducing financial security instruments into maritime conventions. Also inductive approach and historical analysis were used allowing to develop generalised model of maritime law evolution.

\section{Maritime law nature, its codification and evolution of IMO's policy}

The existence of a certain maritime community, which made it possible to find similar solutions both in a technical sense, related to the way of navigation and the importance of similar legal solutions throughout the history, was characteristic of the development of maritime legislation from the beginning of maritime transport. The similarity of solutions adopted in maritime law resulted from its international character and the common perils of the sea. These similarities began to become increasingly difficult to grasp with the advent of the era of great codifications in the eighteenth century, and as a result subordination of maritime law to national policies and legal systems, with their specificity and separateness. The process of subordinating the principles of maritime law to national legal systems and their specificity meant that the maritime law took on a particular character. At the same time however, it underwent an intense "publicization" consisting in increasing interference of public-law instruments, mainly administrative ones, in the sphere of regulating relations under civil law. That mechanism resulted in a far-reaching entanglement of norms belonging to various basic branches of law [1]. The need to undertake works harmonizing the maritime law, somehow "anew", was first discussed in the twentieth century.

The basic instrument of harmonization and, in the long term, the unification of maritime law, were international conventions, drafted basically by the states, and in a few cases also by international organizations. As a result, actions undertaken at the beginning of the twentieth century aimed at unification of private maritime law regulations, and then, along with the development of the public law as a part of maritime law from the mid-twentieth century, they led to shifting the emphasis related to the creation of maritime law to the international level. Maritime law, however, already underwent a major shift compared to the previous centuries. The enormous, centuries-old legacy of private maritime law was supplemented with the public-law part. Its expansion is not a factor characteristic for development of maritime law only, although it was influenced by certain transformations specific to it, related to changes in shipping technology. The turn of the twentieth century was characterized by the broadly understood "socialization" of legal norms, the state's departure from the role of a passive market observer and interventions on the market, increasing humanization of the law and empowerment of the individual as well as strengthening his position in relations with the state. As a result, private maritime law was unified under the auspices of the International Maritime Committee, which resulted in the adoption of Brussels Conventions dealing with wide range of problems: collisions, salvage, shipowner's liability, bill of lading, maritime liens and mortgages, immunity of state owned ships, civil and penal jurisdiction in case of collision, ship arrest. In contrast, the public part of maritime law, from the mid-twentieth century, was created and unified within the 
framework of IMO, the UN agency and the only international organization dedicated exclusively to maritime affairs [2].

The first half of the twentieth century changed the proportions in terms of the intensity of development of both parts of maritime law: private and public. Two world wars and a new balance of power in the world (as a result of decolonization and the Cold War) made the states put a greater emphasis on regulating the issue of ocean management. Maritime law in its public-law part irreversibly became a part of what we currently define as international public law. The growing importance of social issues, the threat to the marine environment resulting from the shipment of new raw materials by sea, such as oil - caused that the role of states in the administration of shipping became increasingly important and thus the growing importance of maritime public law.

The first task of the IMO was to prepare a new version of the SOLAS convention. In addition, the IMO assumed responsibility for developing and promoting regulation on the prevention of marine pollution. During the first few years of activity, the IMO, despite struggling with internal and institutional problems, managed to develop the following: in 1960, a new regulation for preventing collisions at sea [3], in 1965 a new convention to facilitate maritime traffic (FAL) [4], and in 1966, the convention on load lines [5]. It also took over the responsibility for the amendments to the convention adopted in 1954 for the prevention of pollution of the sea by oil (OILPOL).

A new era in the development of IMO's competences was initiated by the Torrey Canyon oil spill in 1967. Similar to the Titanic disaster of 1912, it painfully demonstrated that public maritime law cannot be reduced only to regulating the legal status of maritime zones [6]. That time, however, unlike in case of Titanic, the scale of the threat was greater and included not only the risk of loss of life at sea but also causing irreparable damage to the marine environment. The catastrophe demonstrated the need for such maritime law regulations, which main goal would not be to seek a compromise between states representing different maritime interests, but which could provide a real answer to and solve the global problems arising from these new threats. The complexity of the protection of seas against oil pollution is also illustrated by the joint undertaking of CMI and IMO related to the content of the convention on liability for oil pollution damage. Although they represented different views on the issue of the shipowner's liability rules, the joint effort in this area has shown that private entities (mainly centred in CMI) have realized that the shipping and economic interest cannot remain dominant. The modification of the axiology of maritime law has also been introduced undoubtedly due to the fact that countries traditionally interested in the defence of shipping interests have become aware of the threats to their coast. In other words, also the traditional "shipping" states have recognized the need to protect the interests of coastal states. Therefore, the IMO turned out to be the best forum for conducting negotiations on regulatory measures. The evolution of the IMO's legislative activity indicates increasingly comprehensive regulation of maritime issues. In relation to increasing the level of maritime safety, we can speak first of all about the activities of the IMO concerning the introduction of regulations aimed at increasing safety through structural and operational requirements, but also strengthening these standards by financial compensation instruments.

The current IMO conventions can be divided into four groups. First one being conventions on preventive measures and promotion of enhancing maritime safety [7]. The second group of conventions concerns the area of combating and preventing pollution of the marine environment [8]. The third group consists of conventions for strengthening the level of maritime safety by defining the rules of financial liability in shipping [9]. The fourth category, which is the least numerous one, concerns those conventions whose task is to improve shipping in an economic context, that is to introduce regulations facilitating trade by sea and sanctioning acts unlawfully disrupting maritime trade [10]. 


\section{Introducing the compulsory insurance into maritime law}

The issue of introducing compulsory insurance in the name of realizing public goals consistent with the policy of states became the subject of discussion, also at the academic forum only in the twentieth century. In the nineteenth century, this concept was considered immoral and incompatible with the dominant vision of economic policy [11]. The main risk of introducing compulsory insurance was the greater propensity of insured persons to undesirable behaviour, since the insurance would cover potential damage anyway. Their usefulness as a means of protection of entities whose protection is part of the implementation of the state's duties and which, in the absence of the protection, would be affected in an inadequate way by the negative consequences - has led to their popularization; starting from the motor vehicle insurance introduces in many states in the thirties of XX century to contemporary international conventions.

The important element of consolidation of IMO's maritime law system was also introduction of the financial instruments to increase the effectiveness of the international maritime safety standards. Firstly, the new financial security instruments were introduced as a response to environmental threats. Here, we can point that the civil liability rules were introduced not only to oil spill threats but, over time, also to the other environmental threats (HNS convention, wreck convention). At the moment, compulsory insurance accompanied by principle of direct action and certification, are becoming standard provisions in maritime conventions dealing with the liability towards third parties in many areas.

Financial security instruments are private in nature, but they are perceived by the IMO not only as commercial tools, but also as elements of strengthening the maritime safety system. What is more, the compulsory insurance is associated with the intervention of public policy, e.g. environmental (CLC, bunker convention, HNS, wreck convention) and social goals (MLC). The imposition of compulsory insurance can also contribute to a higher standard on board [12], for the simple reason that the insurer or financial provider would think twice before he offers the insurance to the high-risk ship or ship operator.

\section{Compulsory insurance strengthening maritime safety and environmental protection}

Civil liability conventions are those legal instruments where insurance clearly serves as a tool for achieving IMO's goals relating to the maritime safety and environmental protection of the seas.

First convention that effectively introduced the compulsory insurance in maritime affairs was the International Convention on Civil Liability for Oil Pollution Damage from 1969 (CLC 1969). It has been adopted at the Brussels conference held in the aftermath of Torrey Canyon catastrophe which attracted the worldwide attention to a danger inherent in transportation of large amounts of oil via sea. In fact, at the Brussels conference two conventions were adopted as an international answer to challenges posed by the oil pollution disaster. First, the International Convention Relating to Intervention on the High Seas in Cases of Oil Pollution Casualties. It resolved the problem of coastal state's legal grounds to intervene on the high seas in order to prevent, mitigate or eliminate danger to its coastline or related interests from pollution by oil or the threat thereof, following upon a maritime casualty. The CLC 1969, on the other hand, was intended to set a liability regime, allowing compensation to victims of oil pollution, regardless of the flag of a vessel which became a source of pollution. In 1969 different views, supported by variety of conflicting interest, on how such liability regime ought to work, were confronted. Countries with large shipping interests aimed at lowering shipowner's exposure to liability while coastal states insisted on shipowner's strict liability with high limits. Finally, consumers' interests were 
also represented by states that receive large amounts of oil and sought for placing liability on shipowners primarily, not the oil receivers [6]. Finally, a balanced regime of liability was introduced where burden of compensation was shared between shipowners (via CLC 1969) and oil receivers, on basis of an accompanying convention - International Convention on the Establishment of an International Fund for Compensation for Oil Pollution Damage, 1971. The International Fund for Compensation for Oil Pollution Damage was financed by the oil receivers and existed as a second tier of compensating oil pollution victims, providing redress for victims not fully compensated by the shipowners and their insurers, as well as indemnifying shipowner from part of his liability. CLC 1969 is based on strict liability of the shipowner, with limited grounds for exoneration. Thus, the Convention deviates from liability based on fault, which traditionally has been accepted in maritime affairs. Furthermore, as in the shipping reality it is not uncommon that shipowners try to limit their exposure by creating one ship companies, in order to make shipowner's strict liability feasible, a requirement of financial security has been incorporated. Without it, strict liability in many instances could be illusory. Moreover, compulsory insurance has been equipped with a direct action (actio directa) against the insurer. This way, another traditional in maritime affairs rule has been reversed. Main insurers of third party liability, the P\&I clubs, functioned on 'pay to be paid' basis, according to which the clubs reimbursed the insured that compensated third party. Direct action stands against that rule and simplifies claims recovery procedure, making it more accessible to claimants. Compulsory insurance from the CLC 1969 provides for a limited number of defenses available to insurer. He may not invoke defenses based on an insurance policy. He may though deny cover in cases of shipowner's willful misconduct. The CLC 1969 required such insurance being attested by a certificate carried on board of a ship. Unless financial security is in force of a ship, it will not be allowed to enter or leave a port or an off-shore terminal.

History of compulsory insurance in maritime liability conventions, commenced in 1969 , has proven to be successful. The 1992 protocol to CLC 1969 (CLC 1992) adopts the same pattern. The protocols have introduced multiple changes to the oil pollution liability system, including inter alia raising shipowners' and Fund's limits of liability, specifying definition of pollution damage and vessel, applying convention to the EEZ. No amendments however were added to compulsory insurance measures, besides those relating to issuance and recognition of certificates attesting insurance. Since nowadays 137 states, representing $97.92 \%$ of the world tonnage, have adopted CLC 1992, obligatory insurance in pollution liability is commonly accepted. Moreover, it has become a regular element of other liability schemes. Compulsory insurance accompanying strict liability has been adopted by other maritime conventions: the International Convention on Civil Liability for Bunker Oil Pollution Damage of 2001 (Bunker Pollution Convention), Protocol to the International Convention on Liability and Compensation for Damage in Connection With the Carriage of Hazardous and Noxious Substances by Sea of 2010 (HNS 2010), the Nairobi International Convention on Wreck Removal of 2007 (WRC), as well as Athens Convention Relating to the Carriage of Passengers and Their Luggage by Sea of 2002 (Athens Liability Convention 2002).

\section{Compulsory insurance strengthening social goals}

Introduction of compulsory insurance in relation to the protection of persons has been considered in the IMO forum since the end of the nineties of the twentieth century. As mentioned above, the concept of introducing compulsory insurance for damage to the passenger (death or personal injury of passenger) was realized through the adoption of the Protocol to the Athens Convention in 2002. 
The use of financial security instruments in relation to the protection of persons has recently taken place also in relation to seafarers. This is a new and interesting element of maritime legislation, because in the case of abandoning seafarers or injuries to seafarers, there are no disastrous consequences of a maritime accident as in the case of pollution of the marine environment or there are no such a significant number of victims as in the case of passenger ships' accident.

The basic arguments justifying the introduction of compulsory insurance in relation to shipowners liability for the death or personal injury or abandonment of seafarers was more associated with the setting the seafarer's protection within human rights system. It was also seen as consequence of inadequacy of shipowners' profits and seafarers' protection under existing international conventions. Especially the 1993 International Convention on Maritime Liens and Mortgages (MLM) and the 1999 International Convention on the Arrest of Ships were analysed as a way to ensure the financial protection of seafarers wages payment. The conclusion was that none of this instruments addressed the problems related to abandonment, especially in relation to provide mechanism for determining when the shipowner was deemed to have failed in his duty to repatriate [13]. Also the frequency of abandonment cases, long periods of nonpayment the wages and social consequences for families were important elements taken for consideration. It was especially important in case of abandonment, because although the standards P\&I Clubs cover shipowners liabilities arises from death or long term disability of seafarer, repatriation costs and wages after a shipwreck, the same time, the typical standards cover is not dealing with shipowners liability arises after abandonment of a ship. The ITF had been notified of 212 cases of abandonment involving over 3,500 crew members between July 1995 and June 1999. As of 31 January 2017, there have been 248 incidents affecting 3,037 seafarers. Fifty-one per cent of abandoned vessels are general cargo ships or bulk carriers. Twenty-two per cent of abandoned vessels in this list are from the offshore sector. The period of unpaid wages was taken as a starting point for calculating a period of abandonment. The longest abandonment case last 40 months, while the most common period of abandonment takes 9-12 months. [14].

Entering into force the Maritime Labour Convention (MLC) in August 2013 was a great step towards enhancing the seafarer's right. MLC was adopted under auspices of International Labour Organisation but drafted in close cooperation with IMO. MLC is called as a "seafarer's bill of rights" as it is the most innovative of ILO's Conventions, effectively revises 37 of the maritime labour conventions adopted since ILO's establishment in 1920. In 1999 the joint ILO/IMO ad hoc working group to consider the subject of liability and compensation regarding claims for death, personal injury and abandonment of seafarers was established. It was not invited with enthusiasm by all; for example, the International Group of P\&I Clubs stated that there was no need to consider "longer term solutions" in relation to the issue of claims for personal injury or death of seafarers [15]. Joint Working Group has already at its first meeting recognized that seafarers' social and economic security in cases of abandonment, personal injury and death was insufficient. As a consequence of recommendation drafted by Working Group, the Guidelines on Provision of Financial Security in case of Abandonment of Seafarers and the Guidelines on Shipowners Responsibilities in respect of Contractual Claims for Personal Injury to or Death of Seafarers were adopted by IMO Assembly in October 2001 [16]. In relation to abandonment, the most important element was the recommendation for shipowners to arrange financial security system compliant with Guidelines. According to the Guidelines, the financial security system should provide: (a) a right of direct access by the seafarer to the financial security system; (b) sufficient coverage in respect of the elements of abandonment and (c) the applicability of the financial security system to all seafarers irrespective of nationality. Shipowners also should ensure that their seagoing 
ships engaged on international voyages have on board a certificate attesting to the existence of a financial security system in the event of abandonment of seafarers. In relation to compensation for personal injuries or death of seafarers, according to the Guidelines, shipowners should have effective arrangements for the payment of compensation for death or personal injury. At this stage, the Norwegian model was seen as the most satisfying. According to the Norwegian law, ship-owners were held responsible for repatriation of crew members/seafarers and payment of wages. To be registered in the Norwegian international ship register, every shipowner had to provide a guarantee that the crew members/seafarers would be repatriated and eight weeks of their wages would be paid. A ship which failed to meet these requirements was removed from the register.

For next few years two different point of views interfered: the first represented by seafarers (mainly International Transport Workers' Federation) leaning toward the idea of introducing mandatory financial regime; and the second point of view, represented by shipowners' representatives, that the present P\&I coverage was satisfactory and that no other technical solutions were necessary [17]. In 2008, the compromise had been reached in relation to the mandatory character of financial security system. The same time, the idea of introducing the financial security instrument into the newly adopted MLC was raised as many of the issues related to abandonment, such as wages, repatriation and medical care are covered by Title 2 of the MLC. The possibility of introducing harmonized financial security system in case of seafarers abandonment or death/injury was enhance also by MLC wording, which in Standard A 2.5 and A 4.2 stipulates mandatory financial security provided by the shipowner for repatriation costs and contractual compensations due to an occupational injury, illness or hazard.

Also a number of non-mandatory provisions on financial security in cases of workrelated injury or death of seafarers were introduced in Guideline B4.2 of the Code of the MLC. However, the MLC did not cover compensation and various other expenses and thus the existing gap between the MLC and the IMO Guidelines was highlighted. The basic arisen question was: how to enforce liability of shipowners to provide better and quicker financial protection for seafarers.

The opinion was that from the legal point of view in case of abandonment, the shipowner as the employer, was in breach of the contract and as such he is to be liable towards the employee. The consensus was agreed that the financial security system would be the best way to enforce liability arisen in case of abandonment [18]. It was easier to justify introduction of the financial security instrument in case of liability for personal injury or death of seafarers because shipowner's liability was already adequately covered in Regulation 4.2 of the MLC. As a consequence, even if the MLC did not address in detail how the financial security was to be provided, the claims related to all contingencies for personal injuries and death, were covered by the Convention [18]. In 2008 the agreement between governments, shipowners and the seafarers' representative was achieved stating that the amendment to the ILO Maritime Labour Convention 2006 was the best way to create such a mandatory instrument [19]. The amendments entered into force on $18^{\text {th }}$ January 2017.

The works on amendments took nearly 10 years, and finally after their adoption by the Special Tripartite Committee, were subsequently approved by the International Labour Conference at the 103rd annual meeting of the International Labour Organization (ILO) in June 2014. Amendments aims at better protection for seafarers and their families. They established mandatory requirements for shipowners to maintain financial security to cover abandonment of seafarers, as well as death or long-term disability of seafarers due to occupational injury and hazard. A certificate or other documentary evidence of financial security issued by the financial security provider have to be carried on board the ship. 
The dissimilarity of reasoning behind introducing the financial security system into MLC is clearly noticeable. It vary from ratio legis of introducing compulsory insurance in case environmental damages. In relation to seafarers' abandonment or death/injuries claims there is no risk for major harmful disaster. As it was mentioned, reasoning in that cases is more associated with frequency of abandonment cases, long periods of wages' nonpayment and social consequences for families. This matters were set into context of international human rights system and states responsibilities in this area [20]. IMO declaration on its objective for the decade $2000-2010$ as focus on people was also not without significant.

As the MLC's compulsory insurance obligation for shipowners should be analyzed as a part of wider system of compulsory insurance under IMO conventions, it has to be noticed that mentioned above differences lead also to different solutions. In the IMO's liability conventions, like CLC 1992, Bunkers Convention, Athens Convention, Wreck Removal Convention or lately HNS 2010, the compulsory insurance is coupled with the right of direct action against the insurer. According to MLC the compulsory insurance of the shipowner liability for seafarer's personal injury or death system do not obligate shipowners to provide direct access against the insurer. In relation to seafarer's abandonment, MLC require that such a direct action should be provided in national legislation [21]. As a consequence MLC leaves the States a wide degree of flexibility as to how implement the compulsory insurance system. According to the Conventions, compulsory insurance can be adopted as a form of social security system or insurance or a national fund or other similar arrangement.

\section{6 "Added value" of compulsory insurance's from public law perspective}

Although the primary role of compulsory insurance was to assure that shipowner bears the burden of liability, the obligatory insurance has also the preventive effect. That supposition may be argued by several reasons.

First of all, insurers' influence forces higher safety standards. It is due to a fact that risk inherent with particular ship will be reflected by the insurance premiums. The greater expected loss in the view of the insurer, the higher will be insurance premiums. Insurer will scrutinize vessels as the calculation of possible risk is essential for his financial stability. Mistake in that respect might be a source of insurer's bankruptcy [22]. Their knowledge is extensive due to an obligation of disclosure inherent in every insurance contract. Breach of duty to disclose may lead eventually to loss of coverage. Insurers have also other resources at hand to guarantee all necessary information for estimation of expected loss. They may, for instance, include a warranty into the insurance contract safeguarding truthfulness of particular statement provided by the shipowner [22]. An insurance warranty is an essential term of a contract, a firm key promise given by the insured, breach of which has detrimental consequences for the insured. According to the United Kingdom's Maritime Insurance Act of 1906 breach of any warranty effected in loss of insurance cover was automatic and impossible to remediate, even if the term at stake was not materially related to the risk. Under the Insurance Act of 2015 however, breach of a warranty leads to suspension of cover and may be remediated. Moreover, nowadays insurer may rely upon breach of a warranty which is materially related to the risk.

Secondly, compulsory insurance equipped with direct action makes liability unavoidable. It will not be possible to escape it via practice of creating one ships companies. Inevitable liability creates an incentive for shipowners to maintain better safety standards on board of a ship [22].

Finally, insurance that is compulsory eventually reinforces trend to eliminate substandard vessels from the market. Uninsured ship will not be able to call a port of a state 
which ratified conventions with the compulsory insurance requirement. Hence, ships which are in poor condition will not be able to find insurance and consequently will be prevented from sailing [12].

However, willful misconduct defence available to insurer, weakens the preventive effect of compulsory insurance. As E. Røsœg suggests, defence resembles P\&I practices and its existence in the CLC 1969 proves strong influence of insurance market onto maritime conventions shape [23]. He further questions the rightness of such defense, as much as it shifts the burden of risk from insurers (whereas in case of mutual insurance by the P\&I clubs insurers are in fact shipowners) to claimants. He points that abolishing the willful misconduct exception might lead to disturbances of the P\&I insurance market which however could be remediated by stronger discipline within the clubs so that the shipowners likely to willfully misconduct would be refused insurance cover and thus excluded from sailing [23]. Therefore, elimination of willful misconduct defence could in fact reinforce preventive effect of obligatory insurance.

It has been suggested in the doctrine that insurance in fact loosens ties between misconduct and liability. The opinion is that with shifting the burden of claimants' compensation to insurers insured might be tempted not to care about his conduct. That supposition is known ad moral hazard [24]. A. Szpunar points that refraining from liability of a perpetrator to guarantor's liability dilutes preventive effect of liability [25]. It has been however shown above that insurers have resources and interest in controlling quality of insured vessels. They influence shipowners to maintain high standards on board of ships. Thus, compulsory insurance serves as another tool of IMO's efforts to provide safety on seas and preserve marine environment (similarly: [26]).

The conducted research was funded by National Science Centre, Poland, under the contract UMO2016/23/D/HS5/02447 Maritime safety legal system.

The conducted research was funded by National Science Centre, Poland, under the contract 2016/22/E/HS5/00050 Problems of contemporary maritime codes.

\section{References}

1. J. Łopuski, Problemy teoretyczne międzynarodowego ujednolicania prawa morskiego, Problemy prawne handlu zagranicznego, 8, 34, (1984)

2. J. Łopuski, $O$ żegludze $i$ prawie morskim. Wspomnienia i refleksje, (Branta, Bydgoszcz - Gdynia, 2011)

3. International Regulations for the Preventing Collisions at Sea (1960)

4. International Convention on Facilitation of International Maritime Traffic (1965)

5. International Convention on Load Lines (1966)

6. R.M. M'Gonigle, M.W. Zacher, Pollution, Politics, and International Law: Tankers at Sea, 155, 170, (University of California Press, Berkeley, Los Angeles, London, 1979)

7. International Convention for the Safety of Life at Sea, 1974 as amendment, (SOLAS, 1974); Protocol of 1978 relating to the International Convention for the Safety of Life at Sea, 1974, as amended (SOLAS PROT 1978); Protocol of 1988 relating to the International Convention for the Safety of Life at Sea, 1974, as amended (SOLAS PROT 1988); International Convention on Load Lines, 1966 (LL 1966); Protocol of 1988 relating to the International Convention on Load Lines, 1966, as amended (LL PROT 1988); Convention on the International Regulations for Preventing Collisions at Sea, 1972, as amended (COLREG 1972); International Convention on Standards of Training, Certification and Watchkeeping for Seafarers, 1978, as amended (STCW 
1978);); International Convention on Standards of Training, Certification and Watchkeeping for Fishing Vessel Personnel, 1995 (STCW-F 1995); Torremolinos International Convention for the Safety of Fishing Vessels, 1977 (SFV 1977); Torremolinos Protocol of 1993 relating to the Torremolinos International Convention for the Safety of Fishing Vessels, 1977 (SFV PROT 1993); International Convention on Maritime Search and Rescue, 1979 (SAR, 1979)

8. International Convention for the Prevention of Pollution from Ships, 1973 (MARPOL 1973); Protocol of 1978 relating to the International Convention for the Prevention of Pollution from Ships, 1973, (MARPOL 73/78); Protocol of 1997 to amend the International Convention for the Prevention of Pollution from Ships, 1973, as modified by the Protocol of 1978 relating thereto, as amended (MARPOL PROT 1997); International Convention Relating to Intervention on the High Seas in Cases of Oil Pollution Casualties, 1969 (INTERVENTION 1969 with Protocol relating to Intervention on the High Seas in Cases of Marine Pollution by Substances other than Oil, 1973, as amended (INTERVENTION PROT 1973); International Convention on Oil Pollution Preparedness, Response and Co-operation, 1990, as amended (OPRC 1990); Protocol on Preparedness, Response and Co-operation to Pollution Incidents by Hazardous and Noxious Substances, 2000 (OPRC-HNS 2000); Convention on the Prevention of Marine Pollution by Dumping of Wastes and Other Matter, 1972, as amended (LC 1972); 1996 Protocol to the Convention on the Prevention of Marine Pollution by Dumping of Wastes and Other Matter, 1972 (LC PROT, 1996)

9. International Convention on Civil Liability for Oil Pollution Damage, 1969 (CLC 1969) with Protocol of 1992 to amend the International Convention on Civil Liability for Oil Pollution Damage, 1969 (CLC PROT 1992); International Convention on the Establishment of an International Fund for Compensation for Oil Pollution Damage 1971, (FUND) with Protocols 1976 (FUND PROT 1976), 1992 (FUND PROT 1992), 2000 (FUND PROT 2000), 2003 (FUND PROT 2003); Convention relating to Civil Liability in the Field of Maritime Carriage of Nuclear Material, 1971 (NUCLEAR 1971); International Convention on Civil Liability for Bunker Oil Pollution Damage, 2001 (BUNKERS 2001); Nairobi International Convention on the Removal of Wrecks, 2007 (NAIROBI WRC 2007); Protocol of 2010 to amend the International Convention on Liability and Compensation for Damage in connection with the Carriage of Hazardous and Noxious Substances by Sea, 1996 (HNS PROT 2010) (not yet in force);

10. Convention on Facilitation of International Maritime Traffic, 1965, as amended (FAL 1965); International Convention on Tonnage Measurement of Ships, 1969 (TONNAGE 1969); Convention for the Suppression of Unlawful Acts against the Safety of Maritime Navigation (SUA) with Protocol for the Suppression of Unlawful Acts against the Safety of Fixed Platforms Located on the Continental Shelf (SUA PROT); Protocol of 2005 to the Convention for the Suppression of Unlawful Acts against the Safety of Maritime Navigation (SUA 2005);Protocol of 2005 to the Protocol for the Suppression of Unlawful Acts against the Safety of Fixed Platforms Located on the Continental Shelf (SUA PROT 2005), International Convention on Salvage, 1989 (SALVAGE, 1989)

11. S. Shavell, The Geneva Papers on Risk and Insurance, v. 25 (2), 166 - 179, (2000)

12. E. Røsœg, Scandinavian Institute of Maritime Law Yearbook, MarIus No 258, 182 (2000)

13. Report of the IMO/ILO Ad Hoc Expert Working Group on Liability and Compensation regarding Claims for Death, Personal Injury and Abandonment of Seafarers, LEG $81 / 5,5$ January 2000 
14. Analysis of incidents of abandonment for the period 18 January 2017-17 January 2018, submitted by the International Transport Workers' Federation (ITF), LEG 105/4/2, 6 February 2018

15. Provision of financial security liability and compensation regarding claims for death, personal injury and abandonment of seafarers, LEG 83/4/10, 12 September 2001. Joint IMO/ILO ad hoc expert working group on liability and compensation regarding claims for death, personal injury and abandonment of seafarers, LEG 84/10, 31 January 2002

16. Joint IMO/ILO ad hoc expert working group on liability and compensation regarding claims for death, personal injury and abandonment of seafarers, LEG 84/10, 31 January 2002.

17. Progress report on the work of the Joint IMO/ILO Ad Hoc Expert Working Group on Liability and Compensation regarding Claims for Death, Personal Injury and Abandonment of Seafarers, LEG 91/4, 21 February 2006, p. 4 et seq.

18. Progress report on the work of the Joint IMO/ILO Ad Hoc Expert Working Group on Liability and Compensation regarding Claims for Death, Personal Injury and Abandonment of Seafarers, LEG 94/5, 14 March 2008, p. 11

19. Progress report on the work of the Joint IMO/ILO Ad Hoc Expert Working Group on Liability and Compensation regarding Claims for Death, Personal Injury and Abandonment of Seafarers, LEG 96/4/1, 31 July 2009, p.22

20. Report of the IMO/ILO Ad Hoc Expert Working Group on Liability and Compensation regarding Claims for Death, Personal Injury and Abandonment of Seafarers, LEG 81/5, 5 January 2000.

21. M. Pavliha, A.V. Padovan, The law of Marine insurance [in:] D.J. Attard, M. Fitzmaurice, N. A. Martinez Gutierrez, I. Arroyo, E. Belja, The IMLI Manual on International Maritime Law, v. II Shipping Law, 593-594 (Oxford University Press, 2016)

22. M.M. Billah, Effects of Insurance on Maritime Liability Law. A Legal and Economic Analysis, 198, 183, 142 (Springer, Cham, 2014)

23. E. Røsœg, Scandinavian Institute of Maritime Law Yearbook, MarIus No 115, 132 (2001)

24. L. Zhu, X. Pan, LMCLQ 4, 563- 576 (2016)

25. A. Szpunar, Państwo i Prawo, 1, 17-26 (2003)

26. L. Zhu, J. Mar. L. \& Com., vol. 45(1), 63 -75 (2014) 